\title{
Skały w architekturze podkrakowskich kościołów romańskich
}

\author{
Jan Bromowicz ${ }^{1}$, Janusz Magiera ${ }^{1}$
}

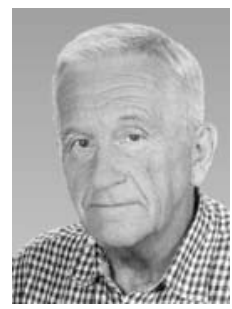

J. Bromowicz

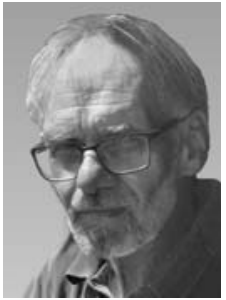

J. Magiera

Rocks applied in the architecture of the Romanesque churches of the northern suburbs of Kraków. Prz. Geol., 67: 728-735; doi: 10.7306/2019.43

A b s tr a c t. There are a few Romanesque churches $\left(12^{\text {th }}\right.$ to mid of $13^{\text {th }}$ century) located iin the close suburbs north of Krakow which are not well known nor described, in contrast to the churches of this age located within the city. Three of them were the subject to the present study. All three churches are located close to each other, but the local geology and available building stones are different. The Romanesque walls of the Church in Prandocin are built of calcareous sandstone of light grayish shade (Neogene). Their exposures and probable past mining sites are located a few kilometers to the north of the church. Stone blocks are very neatly shaped and fitted, so the joints are smooth and very narrow. The church in Wysocice is built mainly of a local compact, white to grayish limestone with cherts (Upper Jurassic), with horizontal stripes made of a porous gray travertine (Quaternary?) adapted to retaining the wall. Sculptures are carved of a soft lithotamnium limestone (Pińczów, Leithakalk; Neogene). Both the compact Jurassic limestone and the soft Pinczów limestone are applied in the church of Kościelec Proszowicki. Decorative sculptures and carvings are made exclusively of the Pińczów limestone.

The works in all three places were performed by masonry guilds, which searched for and quarried an appropriate stone material and treated it. Stonemasons had apparently high qualifications for selecting an appropriate material which, on one hand, fulfilled aesthetical requirements of the founder and, on the other, guaranteed durability of the whole structure.

Keywords: stonework, Romanesque churches, Krakow surroundings

Na północ od Krakowa, w promieniu $35 \mathrm{~km}$ od miasta, stoją trzy kościoły romańskie, w Prandocinie, Wysocicach i Kościelcu. Są to pierwsze kamienne budowle wzniesione w okresie między początkiem XII a połową XIII w. Fundatorami tych budowli były wybitne postacie świeckie i kościelne wczesnego średniowiecza. W ich gestii pozostawały zapewne decyzje związane z kształtem architektonicznym i dekoracją wznoszonych świątyń, a także wyborem warsztatu kamieniarskiego, zwanego strzechą budowlaną. Taki zespół wyszukiwał i wydobywał w najbliższej okolicy stosowny materiał skalny, który był dostarczany na miejsce budowy. Opisywane kościoły, mimo położenia w niewielkiej odległości od siebie, są usytuowane w obszarach różniących się budową geologiczną i możliwościami pozyskiwania odpowiednich skał. Ich wybór jest świadectwem dobrej znajomości cech skał oraz technicznych możliwości wykonawców w zakresie ich poszukiwania, transportu i obróbki. Architektura tych budowli i ich wystrój są dowodem na poczucie estetyki, smaku i harmonii fundatorów tych dzieł.

Odkrywcą romańskiej proweniencji i autorem pierwszych opisów kościołów z Prandocina, Wysocic i Kościelca był w drugiej połowie XIX w. Łuszczkiewicz (1868, 1878, 1891). Stan wiedzy na ich temat po 150 latach badań (wraz z podstawowa literatura) przedstawił Świechowski (2009). W artykule opisano wyniki współczesnych obserwacji kamiennych materiałów użytych do budowy murów i wystroju wnętrz tych trzech romańskich kościołów.

\section{KOŚCIÓŁ W PRANDOCINIE}

Kościół pod wezwaniem Jana Chrzciciela w Prandocinie (ryc. 1) jest usytuowany w pobliżu drogi do Kielc, tuż za Słomnikami. Pierwotnie był to kościół orientowany, długości $19 \mathrm{~m}$ i szerokości $10 \mathrm{~m}$, o ścianach grubości $1 \mathrm{~m}$, zakończony apsydami, z których większa - zachodnia miała średnicę ok. 4,5 m, wschodnia zaś - zamykająca

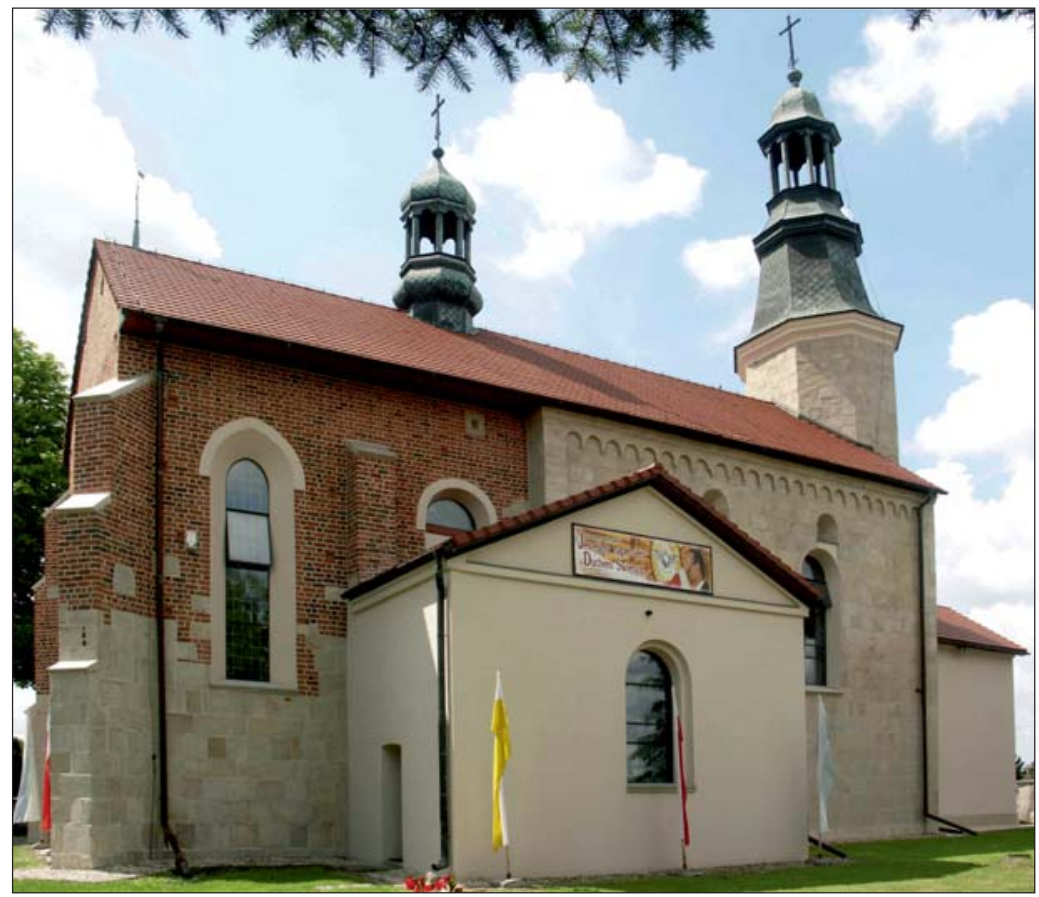

Ryc. 1. Kościół pw. Jana Chrzciciela w Prandocinie

Fig. 1. Church in Prandocin dedicated to Saint John the Baptist

${ }^{1}$ Wydział Geologii, Geofizyki i Ochrony Środowiska, Akademia Górniczo-Hutnicza im. S. Staszica w Krakowie, al. A. Mickiewicza 30,30-059 Kraków; bromow@geol.agh.edu.pl; magiera@geol.agh.edu.pl 


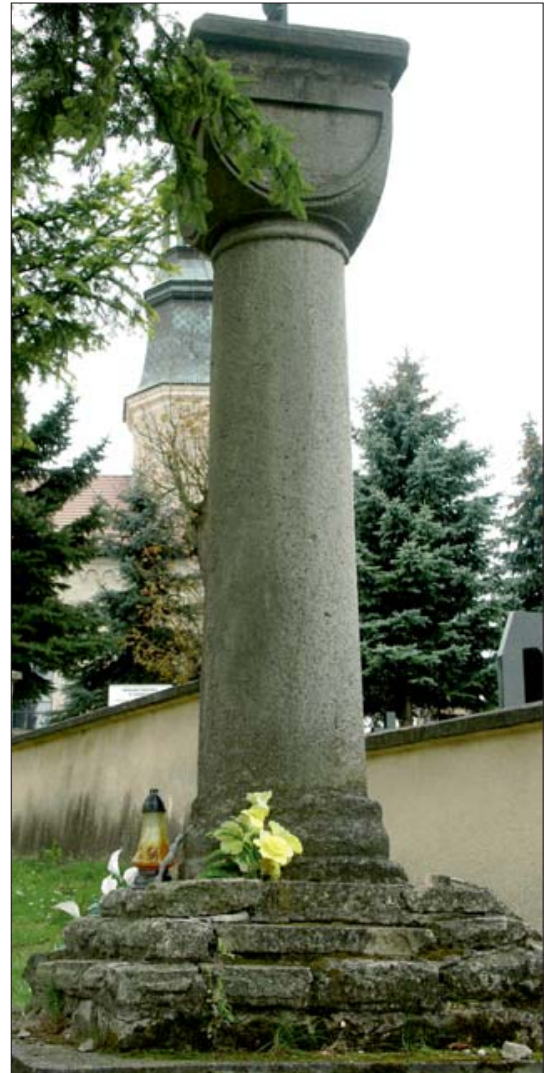

wąskie i krótkie prezbiterium - 3,5 m. W XV w. zlikwidowano wschodnią apsydę, przedłużając kościół w szerokości nawy o ok. 7,5 m. W dolnej części mury dobudówki wzniesiono z kamienia rozebranej apsydy, w górnej zaś z cegły. Romańską część kościoła stanowi nawa z zachodnią apsydą, nad którą wznosi się wieża - okrąła w części dolnej i ośmioboczna w górnej. Druga kondygnacja wieży była otwartą do nawy empora, niegdyś podpartą arkadami spoczywającymi na kolumnie i przyściennych półkolumnach. Kolumna ta została usunięta i ustawiona $\mathrm{w}$ pobliżu sąsiadującego z kościołem cmentarza (ryc. 2). Szczególnym osiągnięciem kamieniarskim jest trzon tej kolumny. Do jej wykonania konieczne było uzyskanie bloku o objętości co najmniej $2 \mathrm{~m}^{3}$, dwumetrowej długości i o wadze ponad $4 \mathrm{t}$.

Mury świątyni mają wysokość ok. $10,5 \mathrm{~m}$, a wznosząca się ponad nimi wieża ma ok. $7 \mathrm{~m}$. Wejście do pierwotnego kościoła było usytuowane po środku ściany południowej i dostępne przez portal zamknięty łukowato przebiegającym ornamentem plecionkowym. Podobnie są zdobione okna świątyni, a ściany upiększa fryz arkadowy (ryc. 3). Okragłą część wieży urozmaicają smukłe półkolumny, a mur nawy - narożne lizeny. Takie dekoracje architektoniczne są, według większości historyków sztuki, znane $\mathrm{z}$ datowanych budowli wznoszonych w Polsce $\mathrm{z}$ początkiem XII w.
Ryc. 2. Kolumna podpierająca niegdyś emporę prandocińskiego kościoła

Fig. 2. Column that supported galleries inside the chuch in Prandocin

Przypuszcza się, że fundatorem kościoła był w pierwszej ćwierci XII w. założyciel Prandocina, komes królewski Prandota Stary herbu Odrowąż. Jako architektonicznie bliźniaczy z prandocińskim i zapewne wzniesiony przez tę samą strzechę budowlaną jest wskazywany kościół w Jędrzejowie, dokumentowany najpóźniej na rok 1118 (Świechowski, 1988; Grzybowski, 1997).

Mury kościoła są zbudowane ze zwięzłych, jasnoszarych, wapnistych piaskowców, wietrzejących na żółtobrązowo i ciemnoszaro. Są one różnie uziarnione. W piaskowcu drobnoziarnistym, wśród jednorodnej masy ziaren sporadycznie wyróżniają się ciemnoszare kwarce (do $1 \mathrm{~mm}$ ) i białe fragmenty muszli (do $2 \mathrm{~mm}$ ). W piaskowcu średnioziarnistym udział rozpoznawalnych składników sięga kilkunastu procent, a w odmianie gruboziarnistej wielkość ziaren kwarcowych dochodzi do $2 \mathrm{~mm}$, podczas gdy w bardzo gruboziarnistej są one jeszcze większe, a fragmenty skorup sięgają $5 \mathrm{~mm}$. Wielkość ziarna jest jednakowa lub też zmienia się, dając pasy niejednolitej grubości różnie uziarnionego kamienia.

W ramach niniejszego studium pomierzono wielkość bloczków kamiennych i uziarnienie piaskowców w ścianie południowej, z historycznym wejściem do świątyni (ryc. 3), oraz $\mathrm{w}$ dobudowanych murach prezbiterium. Pozostałe fragmenty murów romańskich pominięto ze względu na to, że zostały one zrekonstruowane z udziałem dużej ilości obcych skał. Porównanie wielkości kształtek i uziarnienia zastosowanego materiału potwierdziło przypuszczenia o wtórnym użyciu pierwotnego materiału budowlanego do wzniesienia rozbudowanego w XV w. prezbiterium kościoła.

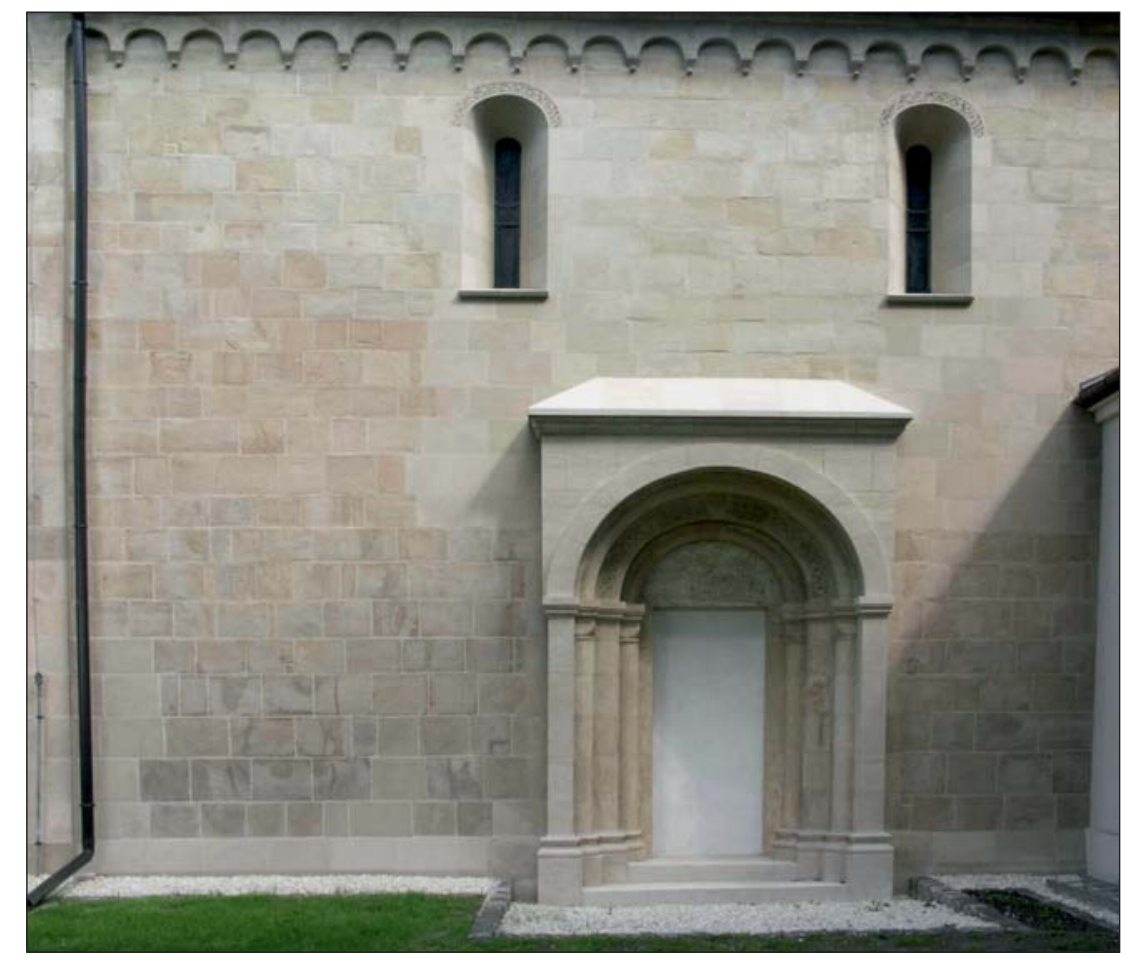

Ryc. 3. Portal w południowej ścianie kościoła w Prandocinie

Fig. 3. Portal in the southern wall of the chuch in Prandocin 
Wymiary 110 bloczków pomierzonych w południowej ścianie kościoła mają średnią wysokość $30,8 \mathrm{~cm}$ i szerokość 33,4 cm, a 412 bloczków z prezbiterium, odpowiednio, 31,8 i $36,5 \mathrm{~cm}$, przy zbliżonych odchyleniach standardowych (tab. 1).
Połowa materiału zastosowanego do budowy ściany romańskiej to piaskowce drobno- i średnioziarniste. Wśród wtórnie użytego materiału stanowią one $62 \%$. Piaskowce o pasmowym ułożeniu ziarna różnej wielkości stanowią 43\% w ścianie południowej i 31\% w prezbiterialnej, piaskowce

Tab. 1. Wymiary kształtek piaskowcowych i wapiennych z kościołów romańskich podkrakowskich i krakowskich (w tym wawelskich) Table 1. Size of sandstone and limestone blocks used in Romanesque churches of Krakow (including Wawel) and suburbs

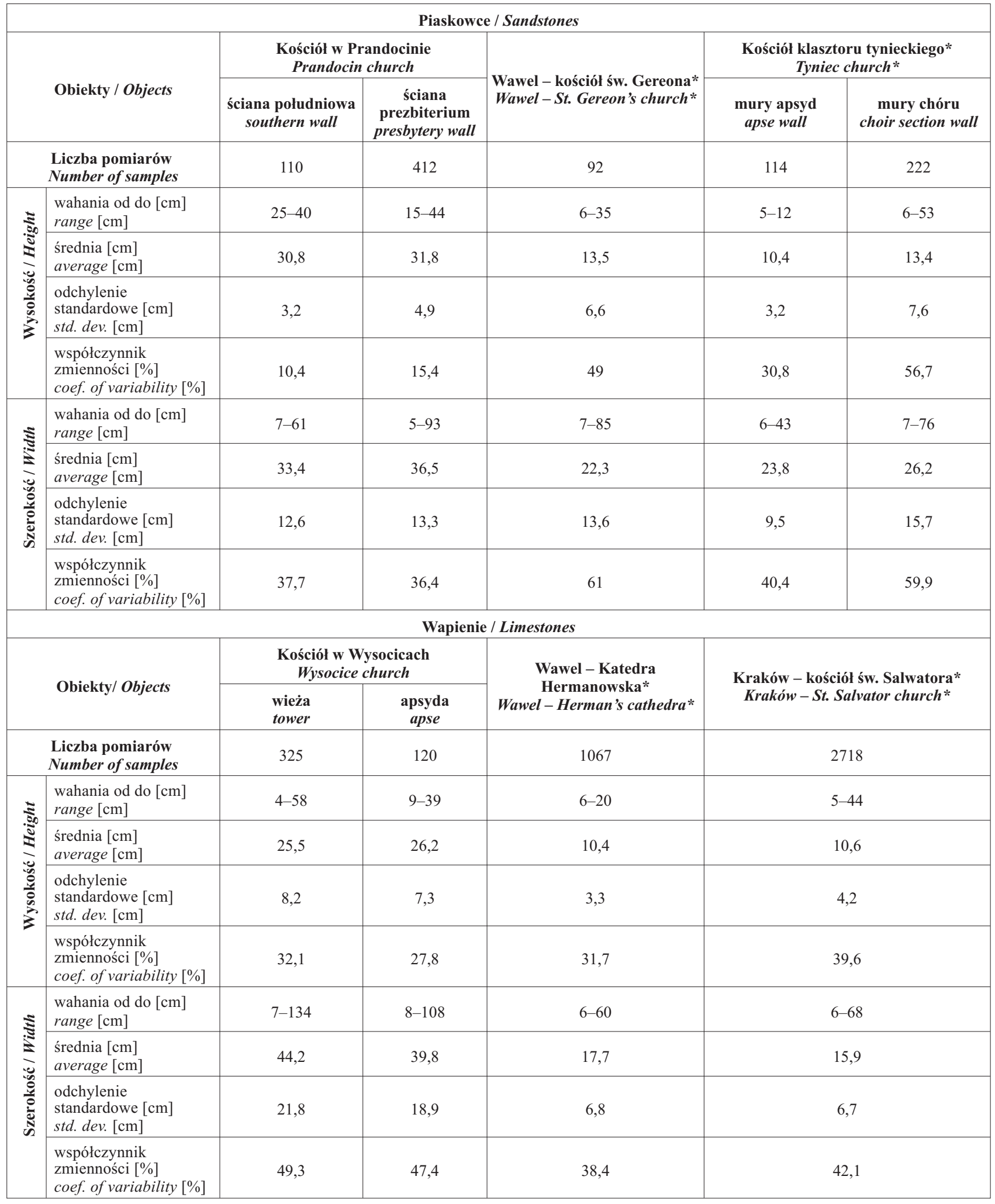

* wyniki pomiarów z pracy Bomowicz, Magiera (2015)

* results taken from Bomowicz, Magiera (2015) 

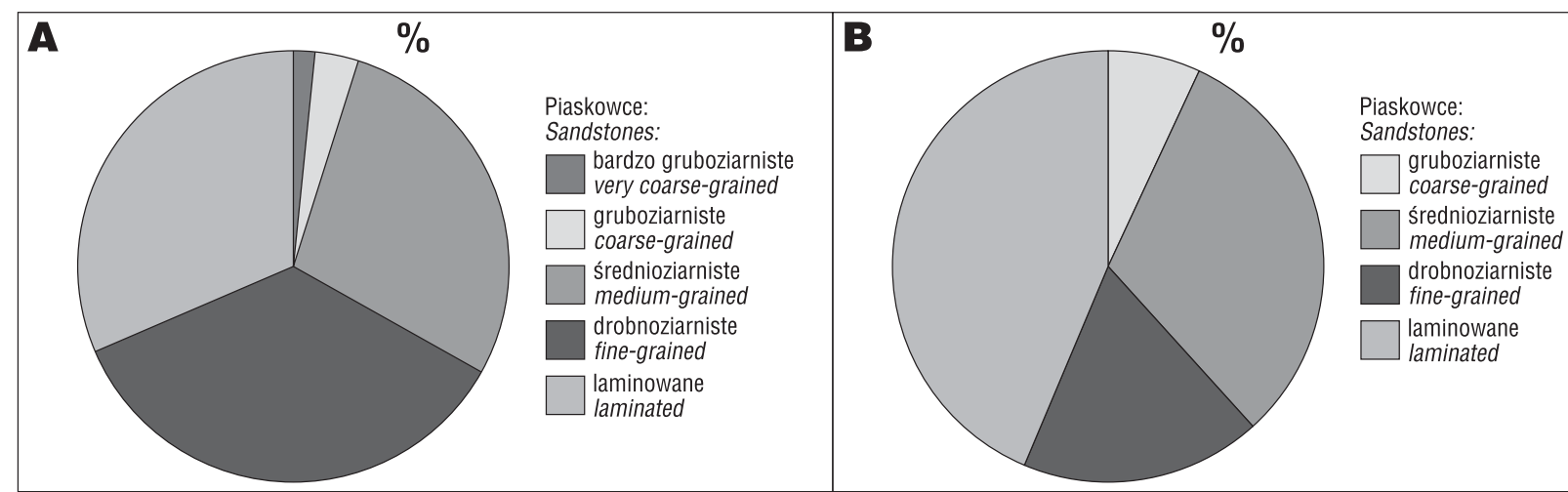

Ryc. 4. Udział odmian piaskowców wyróżnionych w murze ściany południowej (A) i w prezbiterium kościoła w Prandocinie (B) Fig. 4. Distribution of sandstone varieties in the southern wall (A) and in the presbytery (B) of the church in Prandocin

grubo- i bardzo gruboziarniste stanowią zaś odpowiednio $7 \%$ i $5 \%$ (ryc. 4 ).

We wszystkich opisach kościoła jest podkreślana bardzo precyzyjna obróbka kamieniarska materiału. Poszczególne kształtki są dobrze dopasowane, a spoiny między nimi cienkie. Zwraca się też uwagę na precyzję wykonania rzeźby archiwolty oraz wykończenie bardzo subtelnych półkolumn wieży. Wszystko to świadczy o dużym doświadczeniu kamieniarzy i kunszcie ich warsztatu kamieniarskiego. Znamienny jest też wybór skał zastosowanych do budowy kościoła o korzystnych parametrach fizyczno-mechanicznych, warunkujących po 900 latach dobry stan jego zachowania.

W bliskim otoczeniu kościoła nigdzie nie odsłaniaja się piaskowce podobne do tych, które tkwią w jego murach, a trzeba pamiętać, że aby wykonać taką budowlę, konieczne było posiadanie dużej ilości materiału. Do wy-

konania zewnętrznego i we-

wnętrznego lica jednej tylko z dłuższych ścian pierwotnej budowli potrzeba było ok. $50 \mathrm{~m}^{3}$ kamienia (Bromowicz, Magiera, 2018a).

W pobliżu kościoła znajdują się wychodnie węglanowych skał kredowych, powszechnie wykorzystywanych w lokalnym budownictwie, natomiast piaskowce podobne do zastosowanych są opisywane z niewielkich wychodni piaskowców neogeńskiej formacji z Pińczowa, występujących w odległości kilku kilometrów na północny wschód od Prandocina - w Muniakowicach i Nasiechowicach (Boratyn, Brud, 2001). Obecnie, w miejscu - w którym je opisano nie ma wychodni takich skał. W trakcie ich poszukiwania autorzy znaleźli kilkanaście bloków skalnych w podbudowie niedokończonej drogi do zabudowań gospodarczych w Nasiechowicach. Występujące tam piaskowce żywo przypominają piaskowce zastosowane w murach kościoła. Wedle uzyskanych informacji kamień pochodził z pobliskich pól, z miejsc, w któ- rych w czasie orki napotykano piaskowce. Pozyskano je koparką, a powstałe wyrobiska zasypano.

Dwie próbki piaskowca pobrane z bloków skalnych w Nasiechowicach porównano z dwiema próbkami skał z murów kościoła w Prandocinie, uzyskanymi od konserwatorów. Badano również próbkę ze stosowanego w

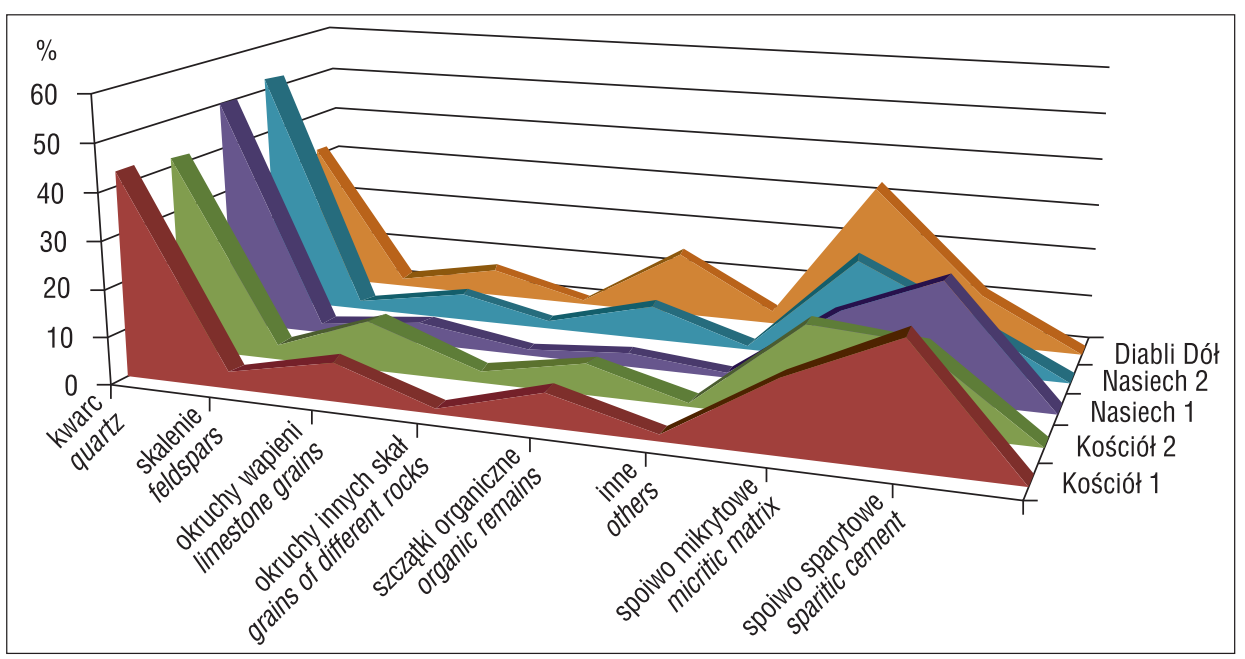

Ryc. 5. Skład petrograficzny pobranych próbek skał

Fig. 5. Petrographic composition of sandstone samples

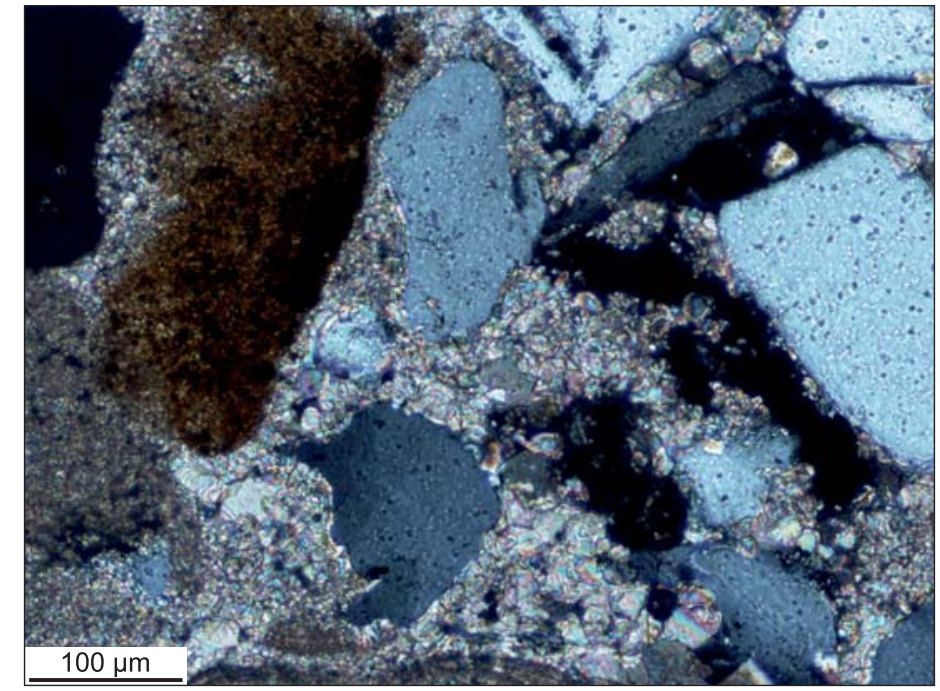

Ryc. 6. Przykład piaskowca z obfitym spoiwem wapiennym

Fig. 6. Example of a sandstone with a high content of carbonate cement 
$\rightarrow$

Ryc. 7. Właściwości fizykomechaniczne badanych skał

Fig. 7. Mechanical properties of examined stones

budownictwie neogeńskiego wapienia piaszczystego, niegdyś pozyskiwanego w wielokrotnie opisywanym w literaturze kamieniołomie, znanym pod nazwą Diabli Dół (Rutkowski, Mądry, 1994). Znajduje się on nieco dalej na północ, w Małaszowie. Obserwacje mikroskopowe wykazały silne petrograficzne podobienstwo badanych prób piaskowców i słabe zapiaszczonego wapienia (ryc. 5).

Piaskowce są sublitycznymi arenitami o obfitym, wapiennym spoiwie, stanowiącym ponad $30 \%$ objętości skały, wykształconym w postaci mikrytu i sparytu, występujących w różnych proporcjach. Okruchy skalne to głównie fragmenty skał węglanowych. Znamienny jest duży udział pokruszonych szczątków organicznych, wśród których można rozpoznać fragmenty otwornic, małży, jeżowców, skorupiaków i powszechnie spotykanych glonów - litotamniów. Obfite wapienne spoiwo i silna korozja kwarcu, zwiększająca powierzchnię kontaktu ze spoiwem (ryc. 6), zapewniały korzystne właściwości fizyczno-mechaniczne piaskowców, znacznie lepsze od wspomnianych wapieni neogeńskich (ryc. 7) czy też skał kredowych występujących na miejscu, ale dosyć miękkich, porowatych, mocno nasiąkliwych i słabo odpornych na działanie warunków atmosferycznych (Rutkowski, Mądry, 1994).

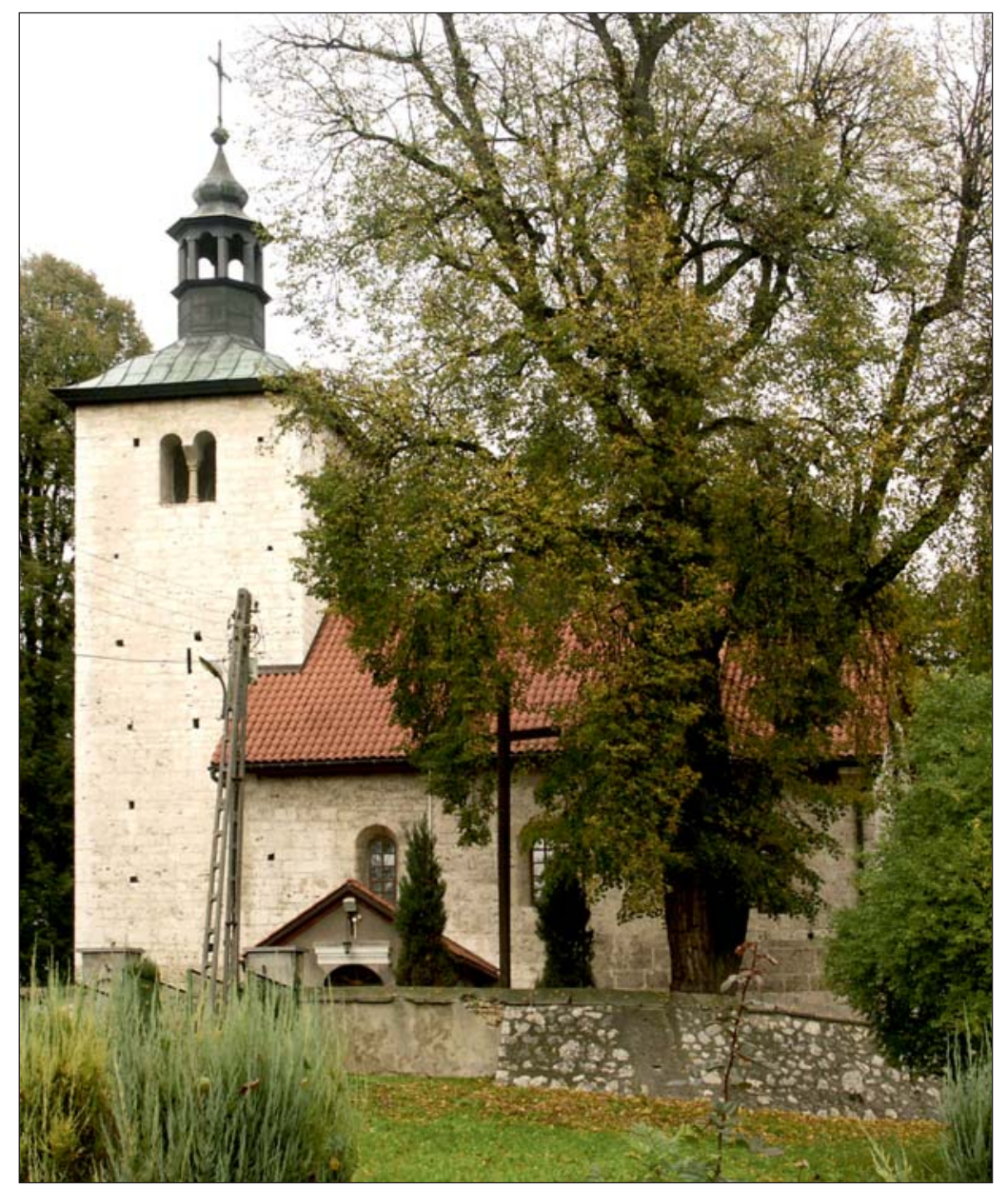

\section{KOŚCIÓŁ W WYSOCICACH}

W Wysocicach, wsi oddalonej o $8 \mathrm{~km}$ na północny wschód od miejscowości Skała oraz $12 \mathrm{~km}$ na północny zachód od Słomnik i połączonej z Krakowem rzeką Dłubnią, znajduje się romański kościół pod wezwaniem św. Mikołaja. Przetrwał on, z bardzo niewielkimi zmianami, około 800 lat.

Prezbiterium kościoła w Wysocicach, o wymiarach 6 × 3 m, łączy się na wschodzie z półkolistą apsydą o promieniu $2,1 \mathrm{~m}$, na zachodzie zaś - z nawą o ośmiometrowych bokach, która przylega do kwadratowej wieży o ścianach długości $4 \mathrm{~m}$. Najniższe piętro wieży jest dostępne jedynie $\mathrm{z}$ nawy kościelnej. Nad nim znajduje się empora zamknięta apsydą, wystającą $\mathrm{z}$ wieży do nawy w formie wykusza $\mathrm{z}$ trzema małymi przeźroczami i śladami ołtarza. Z nawą łączyły ją schody usytuowane w północnych murach świątyni. Wyższe piętra wieży były pomieszczeniami mieszkalnymi, a najwyższe pozwalało na obserwacje okolicy przez otwarte biforia (ryc. 8). Wieża miała pełnić rolę ostatniego miejsca obrony po zajęciu kościoła, który miał stanowić pierwszą zaporę dla wroga. Potwierdza to obecność w środku nawy studni, dziś już zasypanej (Kalinowski, 2013).

W Wysocicach, podobnie jak w Prandocinie, nie zachowały się dokumenty dotyczące czasu budowy kościoła. Przynależność do Odrowążów obszaru, na którym go wzniesiono, a także analiza architektury świątyni wraz z zapisem Jana Długosza o ufundowaniu jej przez krakowskiego hierarchę, wedle większości badaczy wskazują na biskupa Iwona Odrowąża jako fundatora obiektu. Przypuszcza się, że nagła śmierć fundatora w 1229 r. spowodowała przerwę w budowie, a jej zakończenie nastąpiło za sprawą nowego właściciela gruntów - Mikołaja herbu Ostoja, którego godło zostało wyryte w odrzwiach świątyni i którego imię wiązało się z wyborem patrona kościoła (Kalinowski, 2013).

\section{$\leftarrow$}

Ryc. 8. Kościół pw. św. Mikołaja w Wysocicach Fig. 8. Church in Wysocice dedicated to Saint Nicholas 

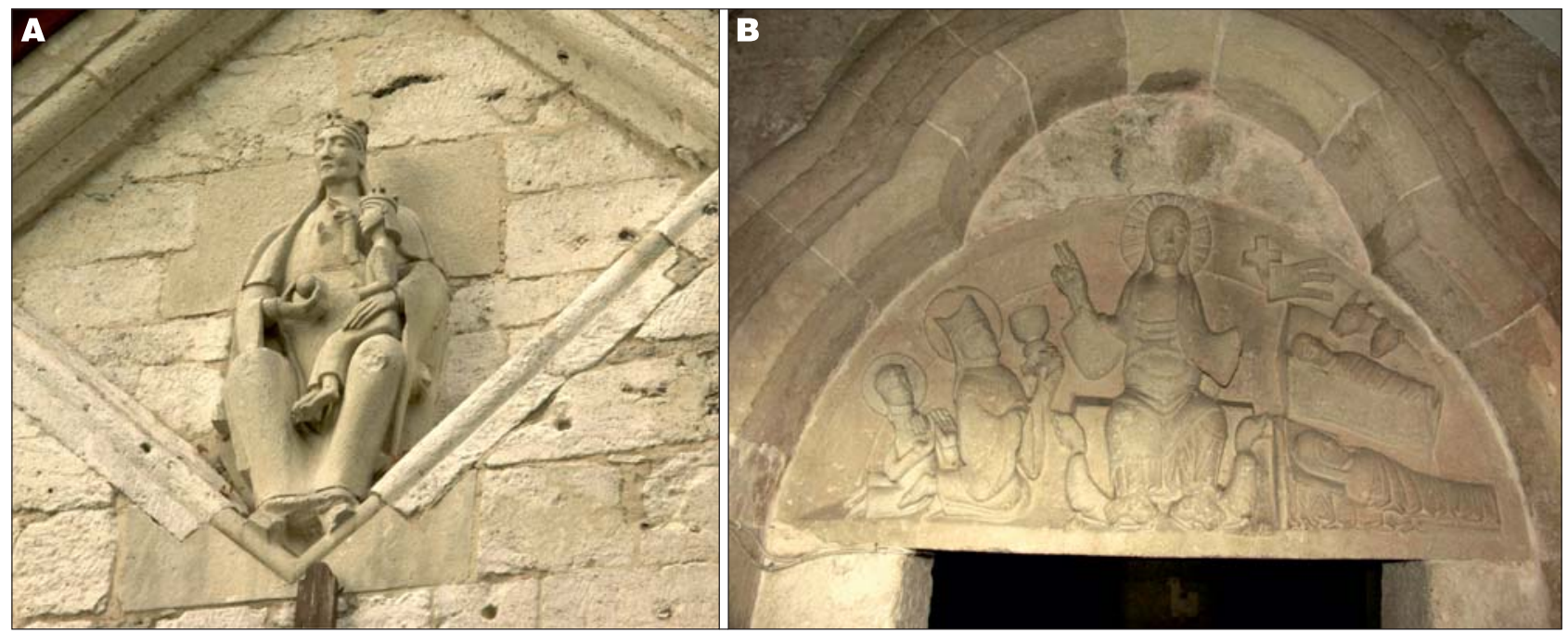

Ryc. 9. Rzeźby w kościele w Wysocicach: A - w szczycie ściany wschodniej; B - w portalu południowym

Fig. 9. Sculptures in the church in Wysocice: $\mathbf{A}$ - atop the eastern wall; $\mathbf{B}$ - inside southern portal

Wystrój architektektoniczno-rzeźbiarski wskazuje, że najbardziej prawdopodobny czas wzniesienia kościoła przypada na pierwszą ćwierć XIII w. Budowla ta, pełniąca rolę twierdzy, posiada dwa wysokiej klasy dzieła sztuki romańskiej. Są to: tympanon nad wejściem do świątyni oraz umieszczona w szczycie prezbiterium rzeźba tronującej Madonny z Dzieciątkiem (ryc. 9).

Głównym materiałem użytym do budowy murów są białe, zwięzłe wapienie jurajskie, z dosyć często pojawiającymi się ciemnobrązowymi krzemieniami. W znacznej większości są to wapienie drobnodetrytyczne o średnicy materiału okruchowego mniejszej od $2 \mathrm{~mm}$ i z kawernami podobnej wielkości. Towarzyszą im wapienie grubodetrytyczne, również kawerniste, z materiałem okruchowym wielkości od 2 do $5 \mathrm{~mm}$. Są też wapienie pelityczne o makroskopowo nierozpoznawalnych składnikach i nieregularnym przełamie muszlowym (Bromowicz, Magiera, 2018b). Udział tych trzech odmian wapieni jurajskich oraz wielkość ich prostopadłościennych kształtek oceniono w ścianach apsydy i wieży do wysokości około 2,5 m nad ziemią. Do wzniesienia obu części świątyni zastosowano podobny materiał, w którym $80 \%$ stanowią bloczki wapieni drobnodetrytycznych, a wapienie pelityczne i grubodetrytyczne po $10 \%$. W porównywanych ścianach kształtki mają wysokość najczęściej w granicach 16,1-32,0 cm i szerokość w przedziale 40,1-48 cm, przy podobnych wartościach średnich (ok. $25 \mathrm{~cm}$ wysokości i 40 cm długości) i współczynnikach zmienności (odpowiednio rzędu 30 i 50\%; tab. 1).

Do budowy murów użyto również bardzo porowatych, holoceńskich trawertynów. Mają one barwy szare, niekiedy brunatne i są ciemniejsze od otaczających wapieni jurajskich. Wielkość detrytycznych składników skały jest bardo różna - osiagga od milimetra do kilku centymetrów. Kształtki trawertynowe mają podobną wysokość jak wapienne, różnią się natomiast szerokością, która waha się od kilku centymetrów, gdy są stosowane jako wypełnienie zbyt szerokich fug pomiędzy wapiennymi bloczkami, do $1,5 \mathrm{~m}$ w przypadku użycia ich jako elementy budowli.

Inne materiały kamienne posłużyły do wykonania detali architektoniczno-rzeźbiarskich. Są wśród nich drobnodetrytyczne, porowate wapienie, z których wykonano rzeźby na frontonie kościoła i nad wejściem oraz trzy kolumny w biforiach wieży (ryc. 10B). Czwarta kolumnaw biforium ściany północnej - została wykonana z piaskowca (ryc. 10A). Wapienie są białe oraz żółtoszare i mają różne uziarnienie. Bardzo drobnoziarnisty jest materiał zastosowany w rzeźbach. Makroskopowo są w nim rozpoznawalne jedynie kilkumilimetrowe, płaskie fragmenty skorup. W grubiej uziarnionych odmianach, użytych do wykonania kolumn, są widoczne kilkumilimetrowe fragmenty bioklastów. Piaskowiec kolumny w północnym biforium wieży jest dosyć zwięzły, drobno- i równoziarnisty, żółtawej barwy. Prócz kwarcu w jego składzie mineralnym można dostrzec liczne nierozpoznawalne szczątki organiczne.

Materiał kamienny wykorzystany do wzniesienia kościoła św. Mikołaja w Wysocicach występuje w niewielkiej odległości od tej budowli, która została posadowiona na wychodni skał kredowych. Użyte w największym udziale wapienie jurajskie z krzemieniami i trawertyny pochodziły prawdopodobnie $\mathrm{z}$ odsłonięć usytuowanych na
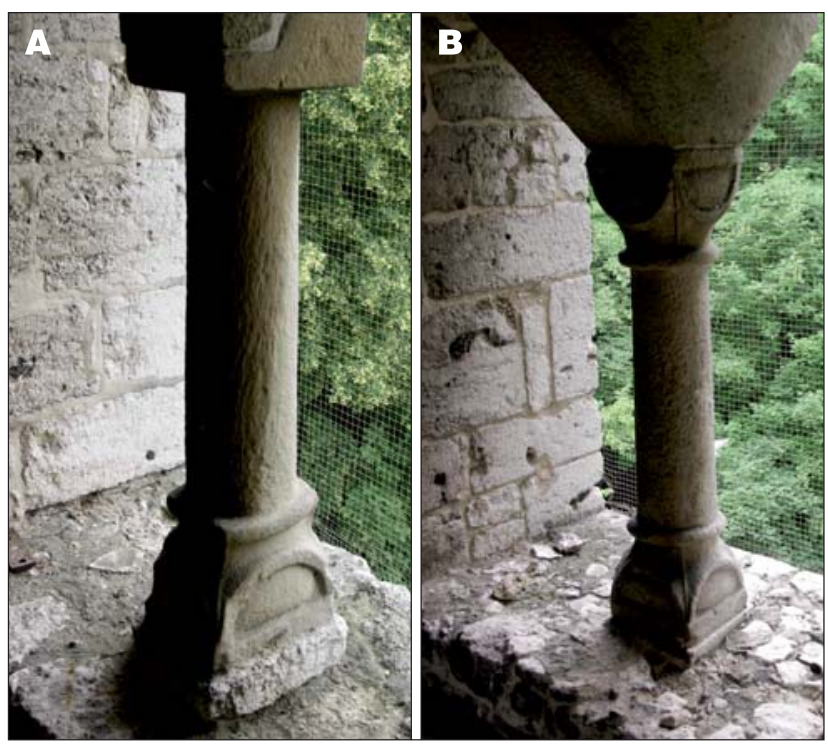

Ryc. 10. Biforia w kościele w Wysocicach: A $-\mathrm{z}$ kolumną piaskowcową; B - z kolumną wapienną

Fig. 10. Biforia in the church in Wysocice: $\mathbf{A}$ - with a sandstone column; B - with a limestone column 
południu, w dolinie Dłubni lub jej lewostronnego dopływu, w odległości $1 \mathrm{~km}$. Łatwiejsze w obróbce i lżejsze od wapieni trawertyny zostały zapewne całkowicie wydobyte. $\mathrm{Na}$ to, że mogły one tam występować w przeszłości, wskazuje obecność podobnych skał w pobliskich Imbramowicach (Płonczyński, 2000). W większej odległości znajdują się wystąpienia porowatych wapieni litotamniowych i wapnistych piaskowców z liczną fauną. Wychodnie

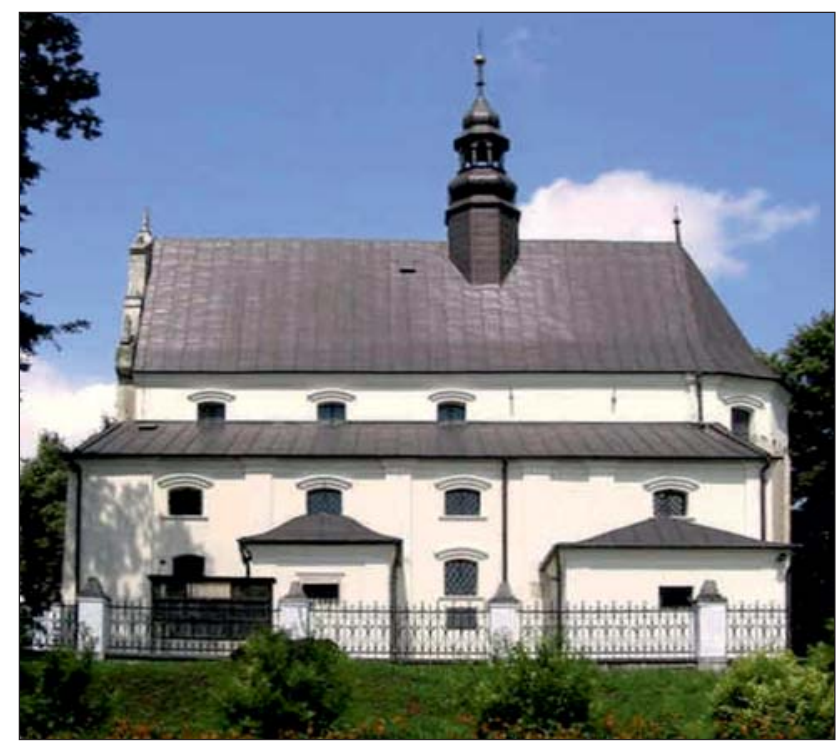

Ryc. 11. Kościół w Kościelcu pod wezwaniem św. Wojciecha. Fot. E. Dobrzańska, www.mierzwa.org.pl

Fig. 11. Church in Kościelec dedicated to Saint Adalbert. Photo by E. Dobrzańska, www.mierzwa.org.pl

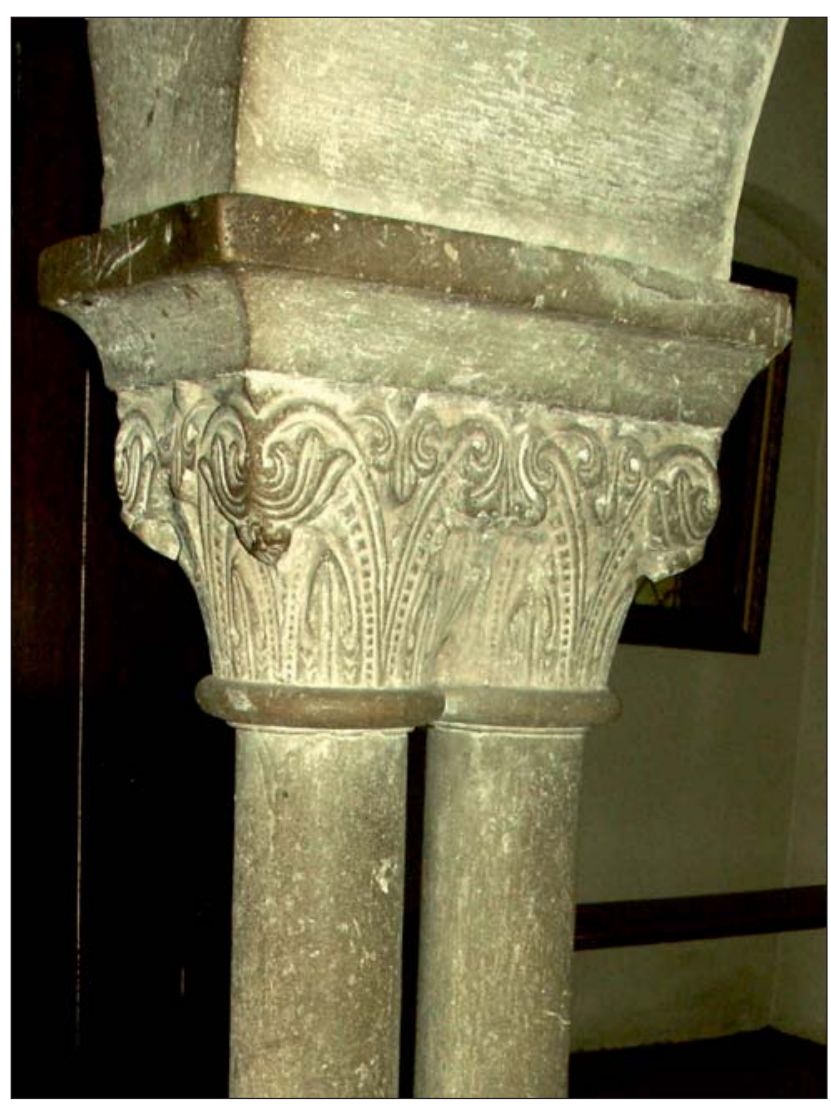

Fig. 12. Głowica kolumny z przeźrocza. Kościół w Kościelcu Fig. 12. Head of the column from the biforium. Church in Kościelec wapieni litotamniowych leżą w odległości ok. $30 \mathrm{~km}$ na północny zachód od Wysocic, w okolicy Sancygniowa i Trzonowa (Rutkowski, Mądry, 1994). Piaskowce wapniste $\mathrm{z}$ fauną są znane $\mathrm{z}$ Nasiechowic, oddalonych od Wysocic tylko o $16 \mathrm{~km}$. Zastosowano je do budowy kościoła w Prandocinie.

\section{KOŚCIÓŁ W KOŚCIELCU}

Kościół kościelecki pod wezwaniem św. Wojciecha (ryc. 11) jest oddalony o ok. 7 km na wschód od Proszowic. Jego architektura odbiega od poprzednich dwóch świątyń. Przed dosyć gruntowną przebudową w XVII w. była to trójnawowa bazylika emporowa o trzech przęsłach korpusu, z prezbiterium zamkniętym apsydą, które sąsiadowało z parą czworobocznych wież wzniesionych na przedłużeniu naw bocznych. Wymiary wewnętrzne prezbiterium to $6 \times 6 \mathrm{~m}$, promień apsydy $-2,5 \mathrm{~m}$, wymiary nawy głównej $6 \times 11 \mathrm{~m}$, szerokość naw bocznych $4 \mathrm{~m}$. Z budowli tej zachował się komplet dwunastu bliźniaczych kolumienek podtrzymujących arkady przeźroczy (ryc. 12). W fasadzie zachodniej przetrwał trójuskokowy portal, zamknięty półkoliście, z wnękami po bokach (ryc. 13).

Kościół został ufundowany w dobrach rodowych przez krakowskiego biskupa Wisława herbu Zabawa, który zastapił wspomnianego biskupa Iwona Odrowąża i sprawował ten urząd w latach 1231-1242, po dwuletnim okresie braku papieskiej nominacji. Świątynia ta ma wybujałą formę architektoniczna, lecz od początku pełniła rolę jedynie wiejskiego kościoła parafialnego. W literaturze są różne przypuszczenia na temat tej rozbieżności. Ostatnio uważa się, że jej wspaniałość miała uzmysławiać wagę

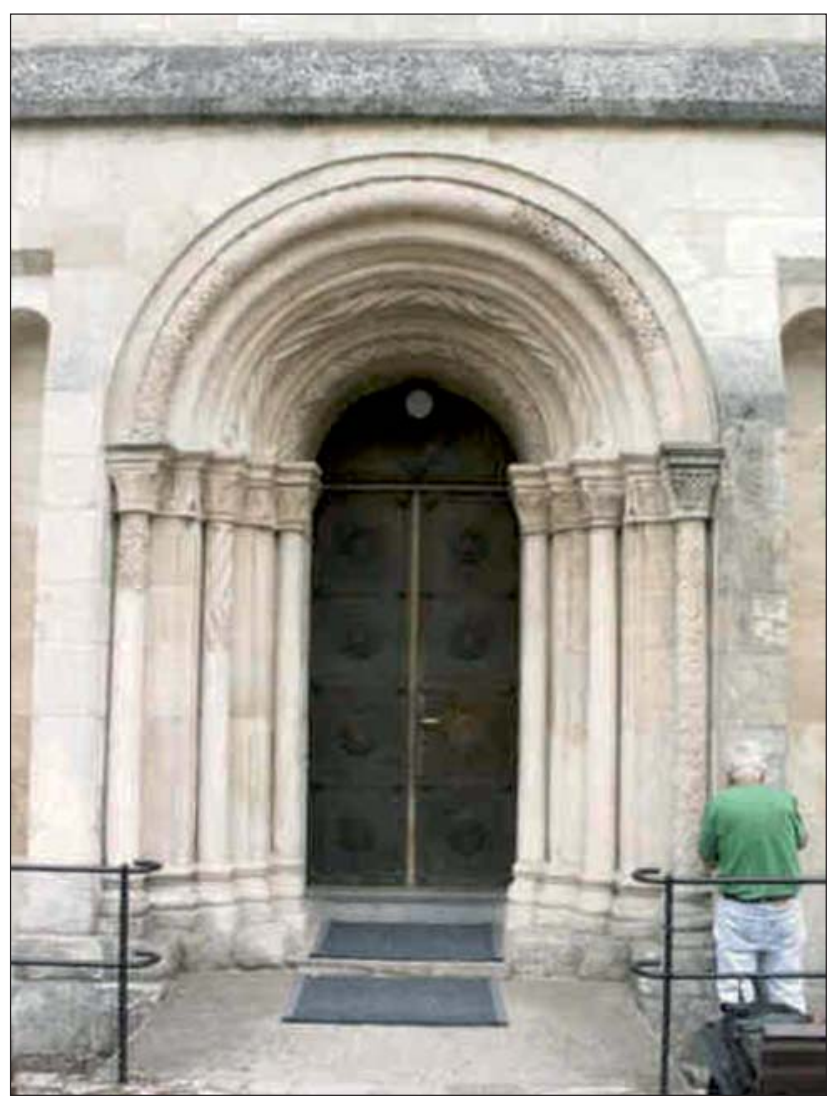

Fig. 13. Domek portalowy zachodniego wejścia. Kościół w Kościelcu Fig. 13. Portal house. Western side of the church in Kościelec 
wyboru biskupa Wisława przez kapitułę krakowska, wbrew oczekiwaniu władz (Soćko, 2009).

Ukryty pod tynkiem kamień murów kościoła jest niedostępny do obserwacji. Według Łuszczkiewicza (1879): Kamień jest wapieniem biatym, zbitym, którego by na próżno szukać przyszło, cała bowiem okolica Proszowic pozbawiona jest materiału kamiennego, a wedle Świechowskiego (2009): Wszystkie elementy architektoniczne o znaczeniu konstrukcyjnym $i$ dekoracyjnym wykonane sa $z$ szarożółtego, drobnoziarnistego wapienia pińczowskiego. Duża część murów jest ceglana. Rozbieżność w ocenie materiału kamiennego wynika zapewne $\mathrm{z}$ obserwacji wykonanych w odmiennych fragmentach budowli, gdzie użyto zarówno wapieni litotamniowych (pińczowskich), jak też górnojurajskich. W obu przypadkach najbliższe ich wychodnie znajdują się w odległości ok. $25 \mathrm{~km}$ od budowli, co zwiększało nakład pracy związany z ich transportem i tłumaczy zastosowanie cegły. Wszystkie kamienne elementy dekoracyjne zostały wykonane $\mathrm{z}$ wapieni litotamniowych, których najbliższe wychodnie są w okolicy Sancygniowa i Trzonowa.

\section{WNIOSKI}

Pierwsze kamienne kościoły wznoszono w Polsce wykorzystując najbliżej położone (do kilkunastu kilometrów) wychodnie skał zdatnych do murowania, o korzystnych parametrach fizyczno-mechanicznych, zapewniających długowieczność wznoszonych $\mathrm{z}$ nich budowli. Występujące na miejscu skały kredowe nie zostały użyte do budowy opisywanych romańskich kościołów. W Prandocinie zastosowano wymagające kilkukilometrowego transportu piaskowce o lepszych właściwościach, w Wysocicach jurajskie wapienie uławicone, a w Kościelcu, gdzie odległość wychodni zdatnych do budowy skał przekraczała 25 km, kamień w dużej mierze zastąpiono cegłą.

Pierwsi kamieniarze wykazali dużą umiejętność w odpowiednim stosowaniu skał o różnych właściwościach fizyczno-mechanicznych. Celem wykonania półprzestrzennych rzeźb sprowadzali do Wysocic, z odległości przekraczającej $30 \mathrm{~km}$, bardzo drobnoziarniste, miękkie wapienie litotamniowe. Do mniej skomplikowanych kolumn w biforiach zastosowali grubiej uziarnione wapienie, a także piaskowce. Jako izolację od wód kapilarnych do budowy murów kościoła wysocickiego wykorzystali silnie porowatą martwicę wapienna, podobnie jak w murach kościołów krakowskich stosowano porowate piaskowce istebniańskie (Bromowicz, Magiera, 2015). Uwzględnili także niewielką wytrzymałość na ściskanie martwicy, sytuując jej warstwę, w obawie przed zbyt dużym obciążeniem skał nadległych, na wysokości nie mniejszej niż ok. 3 m od podłoża.

Mury kościołów budowano $\mathrm{z}$ jednolitego materiału kamiennego w sposób jednakowy, nie różnicując faktury ścian w różnych częściach świątyń. W porównaniu do kościołów krakowskich zastosowano większe kształtki zarówno wapieni, jak i piaskowców (tab. 1), nie wyróżniając doborem ładniejszych skał i lepszą obróbką kamienia najważniejszych części świątyń, co w Krakowie było dosyć częste. Nie zważano na obecność krzemieni w kształtkach wapiennych, których udział był wyraźnie ograniczany w Krakowie. Mimo dużych wymiarów kształtek, zostały one starannie obrobione i dobrze wzajemnie dopasowane, łączone wąskimi fugami. Dużo większe wymiary kształtek wapiennych w kościele wysocickim niż w budowlach krakowskich i większa w nich liczba krzemieni stanowią przesłankę do przyjęcia tezy o większej specjalizacji w wydobyciu i obróbce kamienia w Krakowie. Materiał do budowy opisanych trzech kościołów podkrakowskich pozyskiwano jak leci z naturalnych wychodni, wykorzystywanych prawdopodobnie do wykonania tylko jednej budowli, nie zważając na obecność krzemieni. W Krakowie już z początkiem XII w. było zapewne wiele kamieniołomów wytwarzających małe kształtki wapienne do wielu budowli. Do wznoszenia murów świątyń wykorzystywano tam wapienie bez krzemieni. Bryły wapieni z krzemieniami przeznaczano natomiast do wypełniania wnętrz murów budowanych w technice opus emplectum.

Piaskowce zastosowane w kościele prandocińskim pozyskiwano ze skałek, jakie w przeszłości ukazywały się zapewne na powierzchni ziemi. Kolumna podtrzymująca emporę kościelną z jednolitym trzonem o dwumetrowej wysokości została wykonana zapewne $\mathrm{z}$ bloku pochodzącego ze skalistej wychodni, podobnie jak trzony kolumn z krypty św. Leonarda katedry wawelskiej, pochodzace ze skałek, jakie tworzą karpackie piaskowce istebniańskie. W pobliżu Krakowa prawie wszystkie skałki tych piaskowców zostały wykorzystane na potrzeby budownictwa (por. Bromowicz, 2009).

\section{LITERATURA}

BORATYN J., BRUD S. 2001 - Objaśnienia do Szczegółowej Mapy Geologicznej Polski 1:50 000, ark. Słomniki (947). Państw. Inst. Geol. BROMOWICZ J., MAGIERA J. 2015 - Kamienie wczesnośredniowiecznych budowli Krakowa, ich pochodzenie na tle geologii miasta. Wyd. AGH, Kraków.

BROMOWICZ J., MAGIERA J. 2018a-Historia zapisana w kamieniu. Kościół romański w Prandocinie pod Krakowem. Nowy Kamieniarz, 7 (106): 96-104.

BROMOWICZ J., MAGIERA J. 2018b - Historia zapisana w kamieniu. Kościół romański w Wysocicach pod Krakowem. Nowy Kamieniarz, 5 (104): 96-102.

GRZYBOWSKI A. 1997 - Prandocin po stu latach badań. [W:] Ars sine scientia nihil est. Księga ofiarowana profesorowi Zygmuntowi Świechowskiemu. Dom Wydawniczy ARS, Warszawa: 94-100.

KALINOWSKI R. 2013 - Wysocice, nowe spojrzenie. Komunikat. [W:] Stala K. (red.), III Forum Architecturae Poloniae Medievalis, tom 1. Wyd. Polit. Krak.: 105-130.

ŁUSZCZKIEWICZ W. 1868 - Zabytki dawnego budownictwa w Krakowskiem. Nakł. Pawła Popiela, Kraków.

ŁUSZCZKIEWICZ W. 1878 - Kościół św. Wojciecha we wsi Kościelcu pod Proszowicami, zabytek architektury XIII wieku, Kraków: 42.

ŁUSZCZKIEWICZ W. 1891 - Kościół romański we wsi Prandocin pod Słomnikami. Sprawozdania Komisyi do Badania Historyi Sztuki w Polsce, 4: 16-22.

PŁONCZYŃSKI J. 2000 - Objaśnienia do Szczegółowej Mapy Geologicznej Polski 1: 50 000, ark. Skała (946). Państw. Inst. Geol.

RUTKOWSKI J., MĄDRY S. 1994 - Objaśnienia do Szczegółowej Mapy Geologicznej Polski 1: 50 000, ark. Miechów (915), Państw. Inst. Geol.

SOĆKO A. 2009 - Romańska architektura kościoła pw. św. Wojciecha w Kościelcu Proszowickim - forma a znaczenie. [W:] Janik T. (red.), Architektura romańska w Polsce, nowe odkrycia i interpretacje. Gniezno: 433-453.

ŚWIECHOWSKI Z. 1988 - Pierwotny kształt i chronologia kościoła grodowego w Prandocinie. Kwart. Architek. Urbanis., XXX/ 3: 211-215. ŚWIECHOWSKI Z. 2009 - Katalog architektury romańskiej w Polsce. DiG, Warszawa. 